Section Editor

Mitchell S.V. Elkind, MD, MS

Yong-Won Kim, MD Ji-Hye Seo, MD

Sung-Pa Park, MD, PhD

Yang-Ha Hwang, MD

Correspondence to

Dr. Hwang:

yangha.hwang@gmail.com
Teaching NeuroImages:

\section{Anoxic brain injury with unilateral hemispheric cortical involvement}

Figure $\quad$ MRI showing anoxic brain injury with unilateral cortical involvement
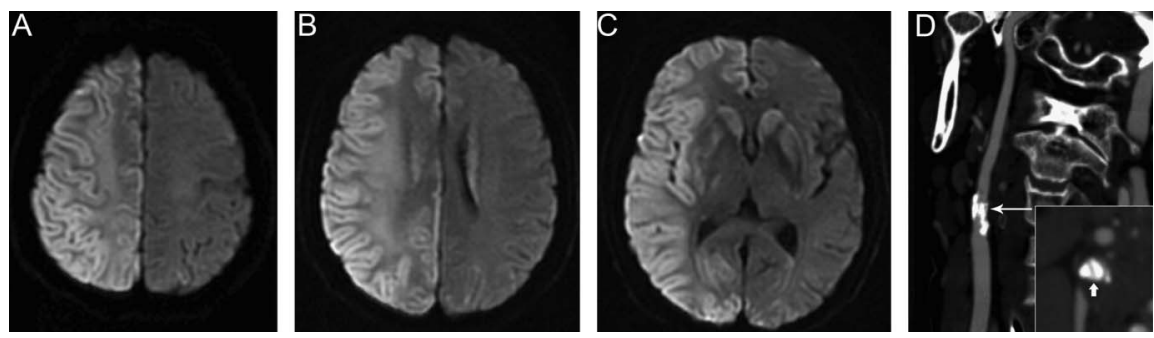

A diffusion-weighted MRI (A-C) shows hyperintensity in the bilateral basal ganglia and the right hemispheric cortex. Curved planar reformation from neck CT angiography (D) reveals severe stenosis (arrow) of the ipsilesional internal carotid artery with heavy calcification.

A 55-year-old woman collapsed with chest pain and cardiac arrest. Her pulse was restored after 6 minutes of cardiopulmonary resuscitation, but she remained comatose. Brain MRI (figure) revealed bilateral basal ganglia and right hemispheric cortical lesion, which was typical for anoxic brain injury ${ }^{1}$ except for the unilateral cortical involvement. Neck CT angiography showed severe stenosis in the right proximal internal carotid artery. The unilateral cortical injury could be explained by compromised cerebral blood flow due to preexisting carotid stenosis. ${ }^{2}$ This case demonstrates an atypical pattern of anoxic brain injury secondary to focal vascular stenosis.

\section{AUTHOR CONTRIBUTIONS}

Study concept and design: Y.-W. Kim, Y.-H. Hwang. Analysis and interpretation of data: Y.-W. Kim, J.-H. Seo. Drafting of the manuscript: Y.-W. Kim.
Critical revision of the manuscript for important intellectual content: Y.-H. Hwang, S.-P. Park.

\section{STUDY FUNDING}

No targeted funding reported.

\section{DISCLOSURE}

The authors report no disclosures relevant to the manuscript. Go to Neurology. org for full disclosures.

\section{REFERENCES}

1. Wijdicks EF, Campeau NG, Miller GM. MR imaging in comatose survivors of cardiac resuscitation. AJNR Am J Neuroradiol 2001;22:1561-1565.

2. Spencer MP, Reid JM. Quantitation of carotid stenosis with continuous-wave (C-W) Doppler ultrasound. Stroke 1979; $10: 326-330$ 


\section{Neurology}

\section{Teaching NeuroImages: Anoxic brain injury with unilateral hemispheric cortical involvement}

Yong-Won Kim, Ji-Hye Seo, Sung-Pa Park, et al. Neurology 2013;80;e160

DOI 10.1212/WNL.0b013e31828ab2dc

This information is current as of April 1, 2013

Updated Information \& Services

References

Subspecialty Collections

Permissions \& Licensing

Reprints including high resolution figures, can be found at: http://n.neurology.org/content/80/14/e160.full

This article cites 2 articles, 2 of which you can access for free at: http://n.neurology.org/content/80/14/e160.full\#ref-list-1

This article, along with others on similar topics, appears in the following collection(s):

Cardiac; see Cerebrovascular Disease/Cardiac

http://n.neurology.org/cgi/collection/cardiac_see_cerebrovascular_dise ase-cardiac

\section{Coma}

http://n.neurology.org/cgi/collection/coma

MRI

http://n.neurology.org/cgi/collection/mri

Information about reproducing this article in parts (figures,tables) or in its entirety can be found online at:

http://www.neurology.org/about/about_the_journal\#permissions

Information about ordering reprints can be found online:

http://n.neurology.org/subscribers/advertise

Neurology ${ }^{\circledR}$ is the official journal of the American Academy of Neurology. Published continuously since 1951 , it is now a weekly with 48 issues per year. Copyright @ 2013 American Academy of Neurology. All rights reserved. Print ISSN: 0028-3878. Online ISSN: 1526-632X.

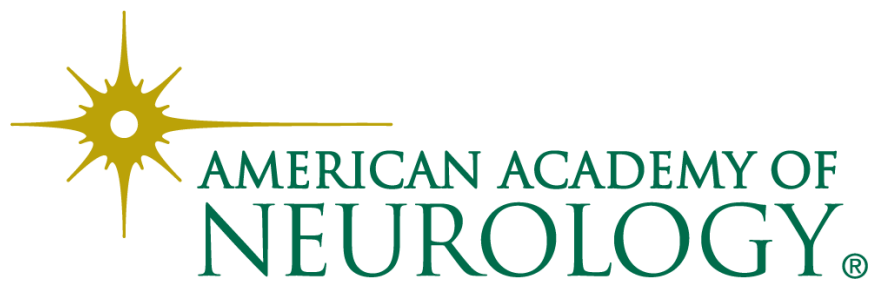

